\title{
FEV1, CTCAE
}

National Cancer Institute

\section{Source}

National Cancer Institute. FEV1, CT CAE. NCI Thesaurus. Code C58186.

An adverse event marked by a change in FEV1 lung function. 